\title{
Partitioning Phosphorus and Potassium in Pecan Trees during High- and Low-crop Seasons
}

\author{
Michael W. Smith ${ }^{1}$ \\ Regents Professor, Department of Horticulture and Landscape Architecture, Oklahoma State \\ University, Stillwater, OK 74078
}

Additional Index words. Carya illinoinensis, fruit, kernel development, cotyledon, alternate bearing

\begin{abstract}
Potassium (K) and phosphorus (P) partitioning were characterized in bearing pecan [Carya illinoinensis (Wangenh.) K. Koch] trees at selected times of the year during three successive years. The first-year trees had little to no crop, followed by a small crop the second year, and a near optimal to excess crop during the third year. Trees bearing a large crop accumulated more $K$ and $P$ in July than trees with little or no crop. $K$ and $P$ content in trees increased from budbreak until July, and then decreased until budbreak the following year. Allocation patterns of $K$ and $P$ among tree components changed during the growing season, with the greatest changes occurring in the annual plant parts. Results indicate that leaves were the principal source of labile $K$ and $P$ for developing fruit. A rapid accumulation of $K$ in the fruit with a concurrent loss from leaves started in July when fruit began a rapid volume increase that continued during carbohydrate deposition in the cotyledon. At first, detectable shuck split K transported to the fruit ceased, but leaf $K$ was partially replenished, presumably from $K$ in perennial tissue because total tree $K$ was static or decreased slightly. In contrast, rapid $P$ transport to fruit began after fruit expansion while cotyledons were developing, presumably associated with oil synthesis and after initial shuck split for storage. Leaf $P$ content continued to decline until leaves were killed by freezing temperatures in the fall. Data indicate that potentially large crops signal additional early season $K$ and $P$ absorption and accumulation in leaves and other tissue long before the fruit are strong $K$ and $P$ sinks. This suggests a complex signaling mechanism, essentially telegraphing a copious demand during the latter part of the growing season.
\end{abstract}

Pecan fruit production is irregular, typified by high production one year followed by one year or more of low production (Sparks, 1986). This may best be characterized as alternate bearing with irregular symmetry. Alternate bearing is typically associated with a lack of return bloom rather than flower or fruit abortion. Certain cultural practices, such as nutrition, light and water management, fruit thinning, vegetation control, and others, reduce alternate bearing intensity, but no management program eliminates irregular bearing.

In central Oklahoma, pecan budbreak is typically the second week in April (Fig. 1). Pecans are heterodichogamous, with pollination during mid- to late May, depending on cultivar. Catkin (staminate flower) differentiation for next year's crop can be detected about 3 weeks after budbreak (Wetzstein and Sparks, 1984). Following pollination, fruit growth is slow and then becomes rapid about the first of July (Diver et al., 1984; McKay, 1947). During fruit enlargement, the endosperm is noncellular. In mid- to late August (for most cultivars), the endosperm becomes cellular (gel stage) and the pericarp begins lignification, ending fruit enlargement. Early August is also when pistillate flower induction occurs for next year's crop (Amling and Amling, 1983); however, differentiation is delayed until bud swell in March (Wetzstein and Sparks, 1983). Deposition of cotyledonary materials (dough stage) immediately follows the gel stage. Fruit ripen (shuck split) in central Oklahoma between early September and early November, depending on cultivar. There are cultivars that produce earlier- and laterripening fruit, but they are not grown in Oklahoma. 'Maramec',

Received for publication 11 May 2009. Accepted for publication 28 June 2009. Funding for this study was provided by the Oklahoma Agricultural Experiment Station, by the Samuel Roberts Noble Foundation, and by the Oklahoma Pecan Growers' Association.

${ }^{1}$ Corresponding author. E-mail: mike.smith@okstate.edu. the cultivar used in this study, ripens the last week in October. The last average spring freeze is $1 \mathrm{Apr}$. and the first killing $\left(-2^{\circ} \mathrm{C}\right)$ fall freeze is 15 Nov. in central Oklahoma (Board of Regents of the University of Oklahoma, 2003).

Potassium and $\mathrm{P}$ are phloem-mobile macronutrients (Marschner et al., 1996) that are readily translocated from leaves to developing pecan fruit (Sparks, 1977, 1988). Potassium functions in osmoregulation, carbohydrate translocation, protein synthesis, enzyme activation, cell expansion, and stomatal regulation (Pallardy, 2008). Potassium is not known to occur in any organic forms. Phosphorus is a constituent of nucleotides, phospholipids, and high-energy phosphate compounds used to transfer energy (Pallardy, 2008). Phosphorous occurs in organic and inorganic forms in the plant and is probably transported in both forms.

Alternate-bearing pecan trees show distinct differences in leaf $\mathrm{K}$ and $\mathrm{P}$ accumulation and depletion between large (ON) and small (OFF) crop loads (Krezdorn, 1955). ON year trees had higher concentrations of leaf $\mathrm{K}$ and $\mathrm{P}$ in April, shortly after budbreak, probably resulting from greater stored reserves following an OFF year. Potassium and P increased in leaves of OFF year trees faster than ON year trees, resulting in similar leaf $\mathrm{K}$ and $\mathrm{P}$ concentrations within 2 weeks after budbreak, and the concentrations remained comparable between fruit production levels, although decreasing, for several weeks. Potassium concentration in leaves of ON trees dropped below that of OFF trees by the end of June and stayed lower throughout the remainder of the growing season. Similarly, Diver et al. (1984) reported that $\mathrm{K}$ concentration in leaves on bearing shoots was less than those on vegetative shoots from late June through September. Diminution of leaf $\mathrm{K}$ during this time period was presumably associated with carbohydrate transport (Haeder, 1977; Mengel, 1980; Mengel and Haeder, 1977; Vreugdenhil, 1985 ) to the rapidly expanding fruit and later in the growing season to developing cotyledons (Diver et al., 1984). 


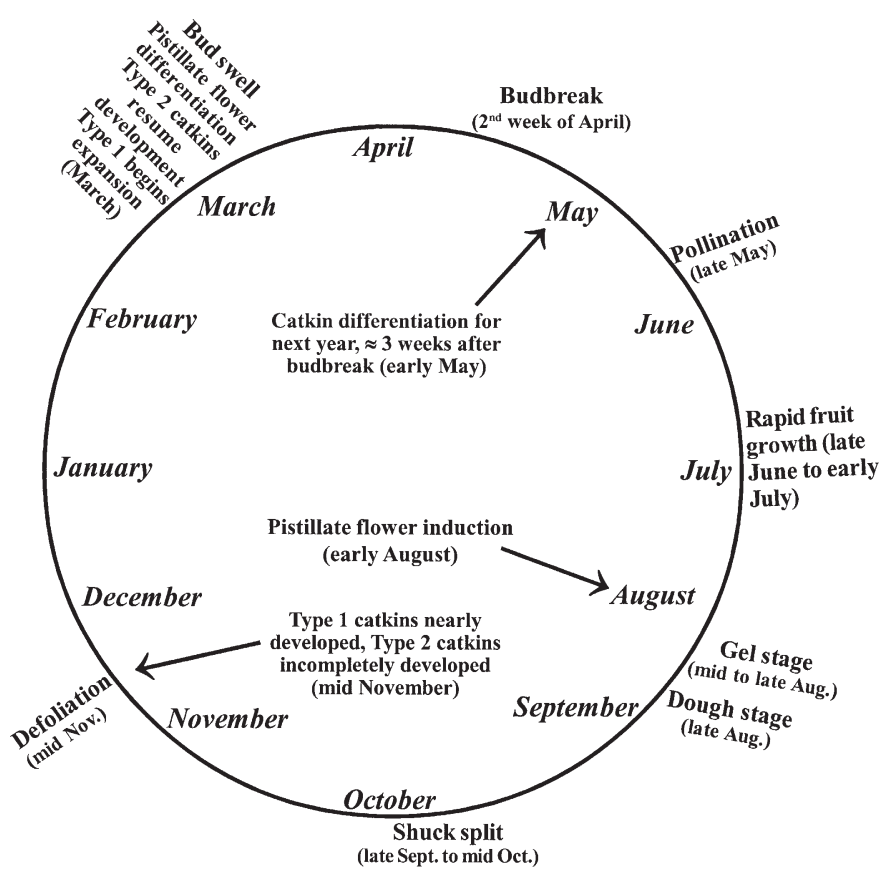

Fig. 1. Annual cycle of pecan phenology and reproductive development. Simultaneous events for the current season crop (outside circle) and next year's crop (inside circle) are identified. The timeline is representative of central Oklahoma. Trees with type 1 catkin development are protandrous and those with type 2 are protogynous.

Phosphorus concentration in leaves of $\mathrm{ON}$ trees exceeds that of OFF trees from late June through mid-August (Krezdorn, 1955). By late August, the leaf $P$ concentration of ON trees dropped below OFF trees, about 6 weeks later than when $\mathrm{K}$ was depleted from leaves of ON trees. The loss of leaf $\mathrm{P}$ coincided with the onset of cotyledon deposition, but not fruit expansion. In another study, leaf $\mathrm{P}$ concentration was similar between fruiting and vegetative shoots throughout the growing season (Diver et al., 1984). However, there was a large accumulation of $\mathrm{P}$ in the kernel during the last 4 weeks before fruit maturity, with the majority accumulating during the final 2 weeks.

Sparks (1977) reported that prolific fruit production frequently resulted in scorched (necrotic leaf margins) leaves in late summer that led to partial defoliation. The concentration of leaf $\mathrm{P}$ in late September was $15 \%$ lower and leaf $\mathrm{K}$ was $25 \%$ lower on shoots where fruit were retained versus those shoots where fruit were removed in July, implicating a critical shortage of one or both of these elements during fruit maturation. The largest accumulation of $\mathrm{K}$ in mature fruit was in the shuck, while the largest $\mathrm{P}$ accumulation was in the kernel. Later work by Sparks (1988) found that a shortage of P created by a strong cotyledon sink resulted in leaf scorch.

Nutrient demand created by developing fruit affects nutrient partitioning in pecan (Acuña-Maldonado et al., 2003; Diver et al., 1984; Smith et al., 2007; Sparks, 1977, 1988) and other orchard crops (Brown et al., 1995; Millard, 1995; Oland, 1959; Picchioni et al., 1997; Stassen et al., 1981; Taylor 1967; Titus and Kang, 1982; Tromp, 1983; Weinbaum et al., 1994a, 1994b, 1994c). Alternate bearing is a significant problem in pecan that may be mitigated by nutrient management (Wells and Wood, 2007). The objective of this study was to elucidate allocation patterns of $\mathrm{P}$ and $\mathrm{K}$ at selected times during low- and high-crop years.

\section{Materials and Methods}

Ten 15-year-old 'Maramec' trees growing in a Teller sandy loam (fine-loamy, mixed, active, thermic Udic Argiustoll) at the Cimarron Valley Research Station near Perkins, OK, were selected based on uniformity of size, vigor, and location within the orchard. Trees were spaced $12.2 \times 12.2 \mathrm{~m}$ and were $9.3 \pm 1.2 \mathrm{~m}$ tall with $29 \pm 3-\mathrm{cm}$ diameter trunks measured $1.4 \mathrm{~m}$ above the ground at the start of the study. A 7.3-m-wide vegetation-free area was maintained the entire row length with selected herbicides. Trees were drip irrigated based on the model developed by Worthington (Worthington and Stein, 1993). Pest management was according to Oklahoma Cooperative Extension Service recommendations (Smith and McCraw, 1998; von Broembsen et al., 1999).

Trees received nitrogen $(\mathrm{N})$ application annually as a single application the second week of March or as a split application with 60\% applied in March and 40\% applied the first week in October. The annual $\mathrm{N}$ application was $125 \mathrm{~kg} \cdot \mathrm{ha}^{-1}$ whether applied as a single or split application. Nitrogen treatment did not affect $\mathrm{K}$ or $\mathrm{P}$ allocation, therefore, $\mathrm{N}$ treatments were pooled.

Production substantially differed among years. In 1998, there was no harvestable yield, probably the result of abundant production in 1997 (19.1 kg/tree). Yield in 1999 was low (8.8 $\mathrm{kg} /$ tree), and in 2000, the trees were overloaded (22 kg/tree). An exceptionally early fall freeze (7-10 Oct.) in 2000 (Smith, 2002) damaged the crop, preventing normal shuck opening. However, yield was measured by harvesting and weighing the fruit (shucks attached) and then correcting the yield by deducting the shuck weight.

Tissue SAMPLes. Samples included roots, $<1 \mathrm{~cm}$ diameter and $\geq 1 \mathrm{~cm}$ diameter, that were excavated with a backhoe. The root samples were collected from each tree in an area $\approx 1 \mathrm{~m}$ wide, $2 \mathrm{~m}$ long, and $1.5 \mathrm{~m}$ deep. A new location was chosen each time roots were sampled. Root samples were washed to remove adhering soil, dried at $70{ }^{\circ} \mathrm{C}$, and then segments of the roots were cut for grinding. Samples were ground to pass through a 20 -mesh screen, and then 10- to 20-g aliquots were stored in jars until analysis.

The trunk was sampled by boring about $102.5-\mathrm{cm}$ holes with a spade bit $\approx 5 \mathrm{~cm}$ deep. The dead outer bark was discarded, and it was then divided into inner bark and wood. The samples were collected in a vertical line on the trunk to reduce damage, and the holes were then filled with mortar mix. Samples were dried and prepared for analysis as described above.

Ten current season shoots per tree were sampled on each date. Shoots were dried, ground, and an aliquot was stored for analysis. Leaf samples consisted of all leaves (leaflets and rachis) on five current season shoots. Five fruit clusters were collected during each sample date, with the whole pistillate flower or fruit used for analysis, except in 1999 when the mature fruit was divided into shuck (involucre), shell (pericarp), and kernel (embryo, including cotyledons). Samples were prepared as described earlier, with an aliquot stored for analysis.

SAmple time. Sample times were at stage 4 budbreak (Wetzstein and Sparks, 1983) (second to third week of April), pollination (last week of May), the third week of July (beginning of rapid fruit enlargement), first shuck split detected ( $<1 \%$ of fruit; first week of October), and immediately after the first killing freeze in the fall (12 Nov. 1998, 18 Nov. 1999, and 10 Oct. 2000) (Fig. 1). 
Sample ANALYSis. Samples were analyzed for P colorimetrically and for $\mathrm{K}$ using atomic absorption spectroscopy. Samples were redried at $70{ }^{\circ} \mathrm{C}$ for $24 \mathrm{~h}$ before weighing a $1-\mathrm{g}$ sample for digestion (dry ash), extraction, and analysis.

Total $\mathbf{P}$ and K estimation. Trunk diameter was measured annually $1.4 \mathrm{~m}$ above the ground while trees were dormant. Biomass of the various components was estimated from annual trunk diameter measurements using equations developed for pecan (Smith and Wood, 2006). Total P and $\mathrm{K}$ in each tree component were calculated by multiplying the estimated weight by the $\mathrm{P}$ or $\mathrm{K}$ concentration, except for the fruit. Fruit mass was determined by calculating the number of fruit at harvest for each tree based on the mean fruit weight of duplicate 20 -fruit samples per tree and total tree yield. The number of fruit per tree was then used to calculate fruit weight for each tree during the various sample times based on the mean fruit weight of the five fruit clusters $(\approx 20$ fruit/tree) sampled on each date. Total $\mathrm{P}$ or $\mathrm{K}$ in the fruit was calculated from the fruit weight and the P or K concentration. Fruit harvested in 1999 were divided into shuck, shell, and kernel, each part was analyzed for $\mathrm{P}$ and $\mathrm{K}$, and the total $\mathrm{P}$ and $\mathrm{K}$ was calculated for each fruit part. In 2000, the early freeze prevented analysis of the fruit parts because the shuck adhered to the shell and the kernel was incompletely developed.

STATISTICAL ANALYSIS. Data were analyzed for each tree component using a mixed model as a split-plot design with year (crop load) nested within sample date. The interaction (sample time $\times$ crop load) had 10 single-tree replications. Means were compared using the protected least significant difference (LSD) test at the $5 \%$ level. In addition, the gain or loss in the concentration of $\mathrm{K}$ or $\mathrm{P}$ from one sampling date to the next was calculated using the elemental concentration as

$$
\% \text { change }=\left(\mathrm{y}_{2}-\mathrm{y}_{1} / \mathrm{y}_{1}\right) \times 100
$$

where $\mathrm{y}_{1}$ is the elemental concentration at the earlier sample date and $\mathrm{y}_{2}$ is the elemental concentration on the subsequent sample date.

\section{Results}

A significant interaction occurred between sample date and crop load affecting $\mathrm{K}$ and $\mathrm{P}$ content in each tree component. Therefore, the interactions will be discussed throughout this manuscript.

Trees absorbed 590 and $1182 \mathrm{~g} /$ tree $\mathrm{K}$ in 2000 and 1999, respectively, from budbreak (April) to pollination (May), an increase of $23 \%$ to $64 \%$ in total $\mathrm{K}$ content (Fig. 2). The largest accumulation during May was in the wood, followed by leaves and large roots. The most striking change in $\mathrm{K}$ concentration was in the current season shoots, increasing 10- and 19-fold in 2000 and 1999, respectively (Fig. 3), reflecting rapid transport to expanding leaves. Wood and bark had substantial increases in $\mathrm{K}$ concentration during the same period. At the end of May when most leaves were fully expanded, leaves had accumulated 558 to $573 \mathrm{~g} /$ tree $\mathrm{K}, \approx 19 \%$ of the tree's total K content.

Total $\mathrm{K}$ peaked each year during July (Fig. 2). Wood contained the most $\mathrm{K}(\approx 35 \%)$, followed by the large roots $(\approx 25 \%)$ and leaves $(\approx 18 \%)$. In 1998 (no crop) and 1999 (small crop), the leaves contained $753 \mathrm{~g} /$ tree $\mathrm{K}$ in July, and in 2000 (excess crop), the leaves had $845 \mathrm{~g} /$ tree; 12\% more (Fig. 2). Fruit accounted for less than $1 \%$ of the tree's total $\mathrm{K}$ content

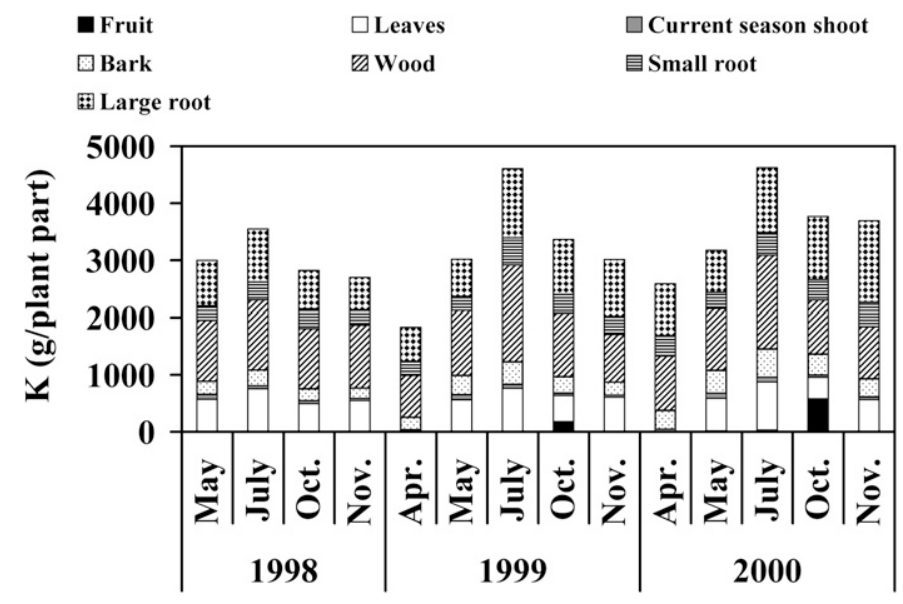

Fig. 2. The influence of differing crop loads among years and time of year on $\mathrm{K}$ partitioning in pecan. Samples were collected 10 Oct. 2000 immediately following a killing freeze rather than in November; otherwise, sample collection was in November after a killing freeze.

in July. In 1999 and 2000 during July, when the trees bore a commercial crop, there was $\approx 4600 \mathrm{~g} /$ tree $\mathrm{K}$, but in 1998 when trees had few or no fruit, $\mathrm{K}$ content was $3548 \mathrm{~g} /$ tree; $23 \%$ less.

Leaf $\mathrm{K}$ loss between the peak accumulation (July) and minimum content (October) was 34\%, 38\%, and 55\% in 1998, 1999, and 2000, respectively (Fig. 3). The reduction in leaf $\mathrm{K}$ between July and October corresponds with accumulation of $\mathrm{K}$ in the fruit (Fig. 2), and the magnitude of $\mathrm{K}$ loss from leaves appears related to crop load. Leaf $\mathrm{K}$ loss during this period was 291 and $467 \mathrm{~g}$ in 1999 and 2000, respectively, while the fruit gained 167 and $549 \mathrm{~g} \mathrm{~K}$. A reduction in $\mathrm{K}$ content occurred in all plant parts, except fruit, in 1999 and 2000, and small roots in 1998 (no fruit in 1998), between July and October each year. Fruit contained $5 \%$ and $15 \%$ of the tree's $\mathrm{K}$ in Oct. 1999 and 2000, respectively (Fig. 2). Following initial shuck split in October, leaf K concentration increased 11\% in 1998, $30 \%$ in 1999, and 49\% in 2000 (Fig. 3). Replenishing depleted $\mathrm{K}$ indicates that leaves remained active between fruit maturity and the killing frost.

Total $\mathrm{K}$ in the tree decreased $24 \%$ in 1998 between the peak content in July and the fall killing freeze (12 Nov.), 35\% in 1999 (18 Nov.), and 20\% in 2000 (10 Oct.) (Fig. 2). During 1999 , the crop matured before the killing freeze in November, but in 2000, the fruit were killed at the beginning of shuck split in October. Fruit contained $175 \mathrm{~g} /$ tree K during October in 1999 and $576 \mathrm{~g} /$ tree $\mathrm{K}$ in 2000, reflecting the larger crop in 2000. Fruit harvested in 1999 that matured normally had $174 \mathrm{~g} /$ tree [kernel: $23 \pm 2 \mathrm{~g} /$ tree, shell: $3.6 \pm 0.4 \mathrm{~g} /$ tree, shuck: $147 \pm 12 \mathrm{~g} /$ tree (mean $\pm \mathrm{SE}$ )], thus, there was no change in fruit $\mathrm{K}$ between initial shuck split in October and harvest. Fruit (shuck, shell, and kernel) contained 5\% of the tree's $\mathrm{K}$ in 1999 and $15 \%$ in 2000 at harvest. About $85 \%$ of the fruit's $\mathrm{K}$ is located in the shuck, which is retained in the orchard.

Between Nov. 1998 and the following Apr. 1999 (no crop), bark and large roots gained $\mathrm{K}$, but other perennial parts lost $\mathrm{K}$ (Fig. 3), resulting in a net reduction of $259 \mathrm{~g} /$ tree (Fig. 2). During the same period the following year (small crop), all plant parts, except large roots, gained K (Fig. 3) and consequentially, trees gained $138 \mathrm{~g} /$ tree $\mathrm{K}$.

In 1999, trees gained $159 \mathrm{~g} /$ tree $\mathrm{P}$ between April and late May (Fig. 4), with the greatest P increase in the leaves (Fig. 5). 

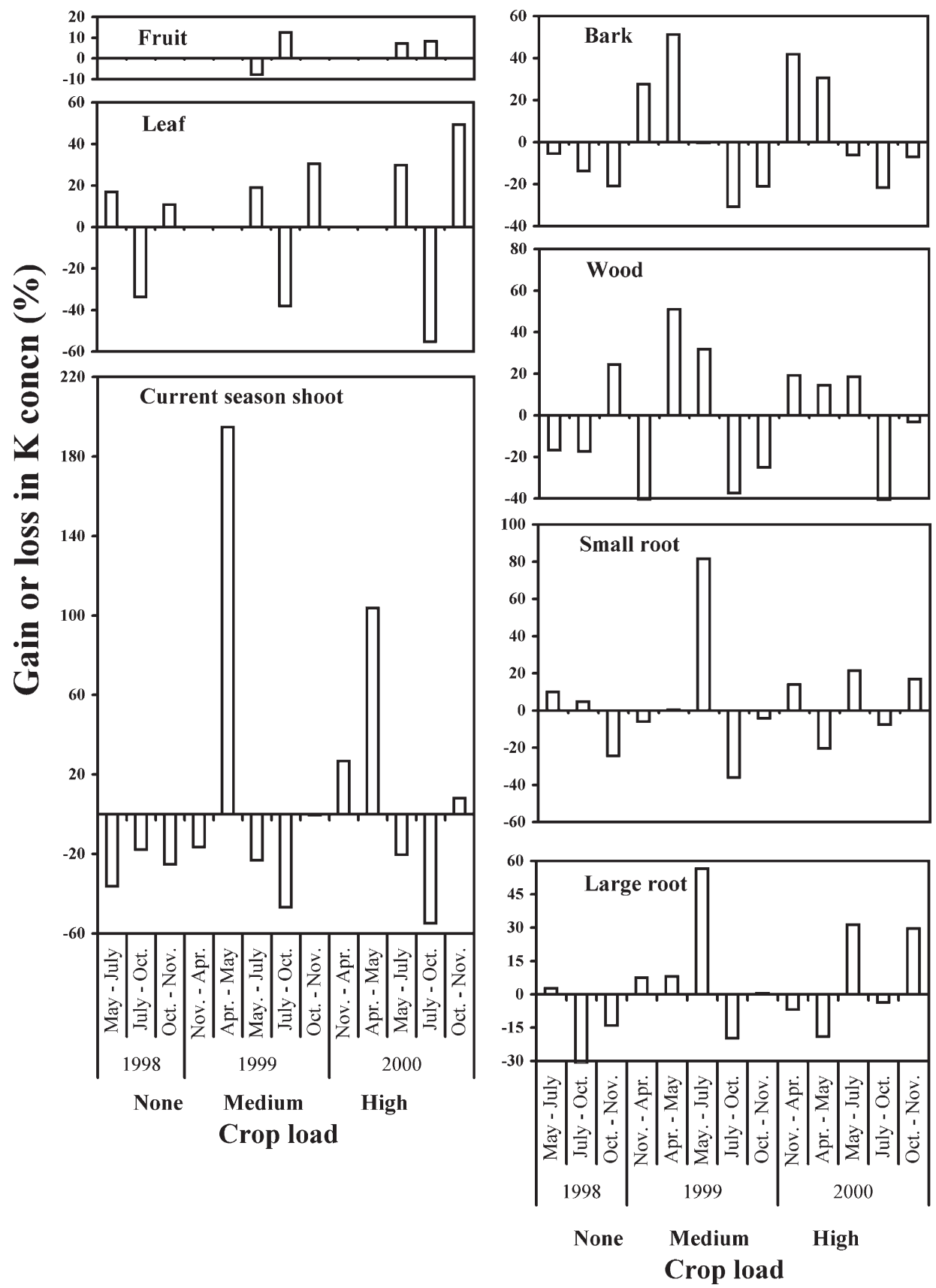

Fig. 3. The influence of differing crop loads among years and time of year on the change in $\mathrm{K}$ concentration in selected plant parts of pecan. Samples were collected 10 Oct. 2000 immediately following a killing freeze rather than in November; otherwise, sample collection was in November after a killing freeze.

Phosphorus in perennial parts was unchanged or increased slightly. Trees lost $159 \mathrm{~g} /$ tree during the same period in 2000, although the expanding leaves had $136 \mathrm{~g} /$ tree. Large declines in $\mathrm{P}$ content of perennial parts, particularly the wood and large roots, resulted in a $297 \mathrm{~g} /$ tree drop in the perennial parts. At the end of May, leaves had 100 to $136 \mathrm{~g} /$ tree $\mathrm{P} ; 28 \%$ to $32 \%$ of the tree's $\mathrm{P}$ content. Fruit contained $<1 \%$ of the total $\mathrm{P}$ in the tree.

Between late May and mid-July, trees gained $\mathrm{P}$ each year (Fig. 4). Most of the P increase was located in the wood in 1998 and 1999, and wood and large roots in 2000. Fruit $P$ remained at a low level, accounting for $<1 \%$ of the tree's P content in July (Fig. 4). Fruit P concentration declined during this period (Fig.
5). Phosphorus content in the leaves decreased between May and July in 1998 and 1999, but increased in 2000.

Between July and October trees lost 236 and $311 \mathrm{~g} /$ tree $\mathrm{P}$ in 1999 and 2000, respectively, but gained $35 \mathrm{~g} /$ tree in 1998 (Fig. 4). The principle difference between losses in 1999 and 2000 and the increase in 1998 was in the wood. Leaves lost $\mathrm{P}$ each year, with the greatest $\mathrm{P}$ decline during 2000 when trees had a large fruit crop (Figs. 4 and 5). Total fruit P increased (Fig. 4), although $\mathrm{P}$ concentration declined (Fig. 5). About 3\% of the tree's $P$ was invested in the fruit during October (initial shuck split).

Leaf $\mathrm{P}$ increased about $2.5 \%$ between October and the November killing freeze in 1998 when there was no crop. However, in 1999 and 2000 , when trees bore a commercial crop, leaf P declined about $20 \%$ between October and the killing freeze. Movement of P from leaves was extremely rapid because there was only a week between the leaf sample taken at initial shuck split and the killing freeze in 2000. In 1999, mature fruit had $22 \mathrm{~g}$ /tree $\mathrm{P}$ (kernel: $15 \pm 1 \mathrm{~g} /$ tree, shell: $1.3 \pm$ $0.1 \mathrm{~g} /$ tree, shuck: $6.3 \pm 0.5 \mathrm{~g} /$ tree; mean $\pm \mathrm{SE}$ ), $5.5 \%$ of the tree's total P. Unfortunately, fruit P content was not determined after the freeze in 2000 because fruit were killed only 1 week following the previous sample. Thirteen percent to $15 \%$ of the tree's P content was lost in the dead leaves following the fall freeze. Total $\mathrm{P}$ in perennial tree parts was static between October and the killing freeze in 1999 and 2000.

\section{Discussion}

Trees bearing fruit accumulated $23 \%$ more K in July than trees with few or no fruit (Fig. 2). Larger amounts of K were partitioned to the wood followed by the large roots and leaves during July. Less than $1 \%$ of the tree's $\mathrm{K}$ was partitioned to the fruit, so their direct impact on early season $\mathrm{K}$ demand was minimal, although their presence may have indirectly affected demand. Substantial amounts of $\mathrm{K}$ were lost from the tree between July and October, regardless of crop load. Reductions in $\mathrm{K}$ content were greatest in the wood and large roots and did not appear related to crop load. It is unclear how $\mathrm{K}$ escaped the tree because annual parts remained in October. Potassium does not enter into any structures and might be lost from tissue, particularly leaves, by the leaching action of water, nonselective 


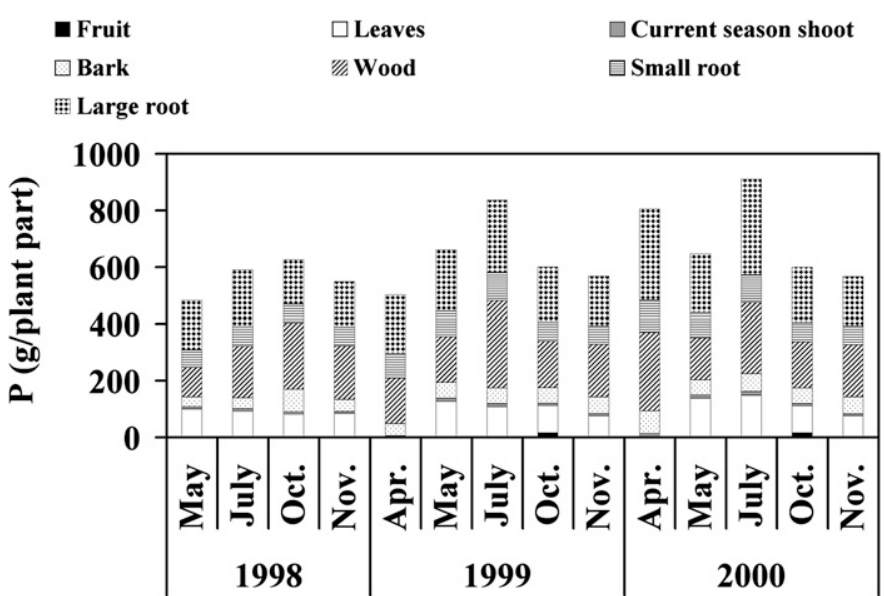

Fig. 4. The influence of differing crop loads among years and time of year on $\mathrm{P}$ partitioning in pecan. Samples were collected 10 Oct. 2000 immediately following a killing freeze rather than in November; otherwise, sample collection was in November after a killing freeze. diffusion from roots, and occasional loss of leaves, fruit, and small roots.

Leaves lost large amounts of $\mathrm{K}$ between July and initial shuck split in October that appeared related to crop load. Apparently, leaves were a principal source of labile K to meet fruit demand, although $\mathrm{K}$ was also available from perennial tree parts. Data indicates that the entire fruit demand was met by reallocation of $\mathrm{K}$ rather than absorption. Others reported leaf $\mathrm{K}$ decreased quickly as it increased in rapidly developing pecan fruit (Diver et al., 1984; Sparks, 1977). Late season K losses from leaves with concurrent accumulation in fruit have been reported for peach [Prunus persica (L.) Batsch.] (Batjer and Westwood, 1958), prune (P. domestica L.) (Niederholzer et al., 1991; Weinbaum et al., 1994c), and mandarins (Citrus reticulata Blanco) (Golomb and Goldschmidt, 1987). Most of the K was partitioned to the pecan's shuck $(85 \%)$ followed by the kernel $(13 \%)$ and shell $(2 \%)$. The increase in shuck and kernel $\mathrm{K}$ as the fruit began rapid size increase followed by accumulation of complex carbohydrates in the cotyledons is presumably associated with $\mathrm{K}$ function in carbohydrate transport (Haeder, 1977; Mengel, 1980; Mengel and Haeder, 1977; Vreugdenhil, 1985). Before initial shuck split, the shuck's water content increases (Thor and Smith, 1935), a process that is partially regulated by $\mathrm{K}$ (Pallardy, 2008).

The principal time for P absorption was from budbreak through July (Fig. 4). After July, loss of P from the tree exceeded any P absorbed. Data from this study did not allow differentiation between reallocation of stored $\mathrm{P}$ and $\mathrm{P}$ absorption. However, $\mathrm{P}$ partitioning within the tree suggests that $\mathrm{P}$ requirement for annual plant parts was by a combination of new absorption and reallocation among tree parts. The amount each component contributed to annual parts and growth of perennial tissue varied among years.

Leaves appear to be the principal $P$ source to meet late season demand of developing fruit (Figs. 4 and 5), similar to their role in supplying $\mathrm{K}$. However, fruit demand for $\mathrm{P}$ occurred later than for K. Transport of $\mathrm{K}$ to fruit rose as fruit began rapid expansion (July), continued until initial shuck split (October), and then remained static (November) (Fig. 2). In contrast, fruit P concentration decreased from May through October (Fig. 5), although there was an increase in total fruit P (Fig. 4) resulting from increased mass. Phosphorus transport to fruit was extremely rapid during the time of shuck split. This transport pattern to developing fruit with depletion from leaves agrees with an earlier report (Diver et al., 1984). Phospholipids in

Fig. 5. The influence of differing crop loads among years and time of year on the change in $\mathrm{P}$ concentration in selected plant parts of pecan. Samples were collected 10 Oct. 2000 immediately following a killing freeze rather than in November; otherwise, sample collection was in November after a killing freeze. 
developing cotyledons are a substrate for unsaturated fatty acid synthesis (Chesworth et al., 1998). Pecan cotyledons are 65\% to $78 \%$ lipids, with major constituents of oleic (monounsaturated) and linoleic (polyunsaturated) acids (Venkatachalam et al., 2007), thus $P$ is a crucial component contributing to kernel development late in the growing season. Phosphorus is also stored in cotyledons as inositol hexaphosphate (phytic acid) (Chesworth et al., 1998), with transport and storage apparently occurring rapidly as the fruit matures. The fruit's massive demand for P late in the growing season can induce necrotic leaf tissue, commonly referred to as leaf scorch, and premature defoliation (Sparks, 1988). Leaf $P$ concentration was higher when the crop load was large [July compound leaf concentration: $0.13 \%, 0.13 \%$, and $0.16 \%$ in 1998 (OFF), 1999 (OFF), and 2000 (ON), respectively], suggesting that a large crop increases early-season $\mathrm{P}$ absorption that is partitioned to the leaves, long before the fruit becomes the dominate $\mathrm{P}$ sink. This suggests a complex signaling process that allows $\mathrm{P}$ accumulation when availability is adequate from the soil.

\section{Literature Cited}

Acuña-Maldonado, L.E., M.W. Smith, N.O. Maness, B.S. Cheary, B.L. Carroll, and G.V. Johnson. 2003. Influence of nitrogen application time on nitrogen absorption, partitioning, and yield of pecan. J. Amer. Soc. Hort. Sci. 128:155-162.

Amling, H.J. and K.A. Amling. 1983. Physiological differentiation of pistillate flowers of pecan and cold requirements for their initiation. J. Amer. Soc. Hort. Sci. 108:195-198.

Batjer, L.P. and M.N. Westwood. 1958. Seasonal trends of several nutrient elements in leaves and fruits of Elberta peach. Proc. Amer. Soc. Hort. Sci. 65:116-126.

Board of Regents of the University of Oklahoma. 2003. Agweather. 1 May 2009. <http://agweather.mesonet.org/index.php/data/section/ climate>.

Brown, P.H., S.A. Weinbaum, and G.A. Picchioni. 1995. Alternate bearing influences annual nutrient consumption and the total nutrient content of mature pistachio trees. Trees (Berl.) 9:158-164.

Chesworth, J.M., T. Stuchbury, and J.R. Scaife. 1998. Agricultural biochemistry. Chapman and Hall, New York.

Diver, S.G., M.W. Smith, and R.W. McNew. 1984. Influence of fruit development on seasonal elemental concentrations and distribution in fruit and leaves of pecan. Commun. Soil Sci. Plant Anal. 15:619-637.

Golomb, A. and E.E. Goldschmidt. 1987. Mineral nutrient balance and impairment of the nitrate-reducing system in alternate-bearing 'Wilking' mandarin trees. J. Amer. Soc. Hort. Sci. 112:397-401.

Haeder, H.E. 1977. Effects of potassium on phloem loading and transport. Fertilizer use and production of carbohydrates and lipids. Proc. Colloquium Intl. Potash Inst. 13:115-121.

Krezdorn, A.H. 1955. The nutrient status of pecan leaves in relation to alternate bearing. Proc. Texas Pecan Growers Assn. 34:43-53.

Marschner, I., E.A. Kirby, and I. Cakmak. 1996. Effect of mineral nutritional status on shoot-root partitioning of photoassimilates and cycling of mineral nutrients. J. Expt. Bot. 47:1255-1263.

McKay, J.W. 1947. Embryology of pecan. J. Agr. Res. 74:263-283.

Mengel, K. 1980. Effect of potassium on the assimilate conduction to storage tissue. Ber. Dtsch. Bot. Ges. 93:353-362.

Mengel, K. and H. Haeder. 1977. Effect of potassium supply on the rate of phloem sap exudation and the composition of phloem sap of Ricinus communis. Plant Physiol. 59:282-284.

Millard, P. 1995. Internal cycling of nitrogen in trees. Acta Hort. 373:3-14.

Niederholzer, F.J.A., R.M. Carlson, K. Uriu, N.H. Willits, and J.P. Peraron. 1991. Seasonal partitioning of leaf and fruit potassium and fruit dry matter in French prune trees at various potassium levels. J. Amer. Soc. Hort. Sci. 116:981-986.

Oland, K. 1959. Nitrogenous reserves of apple trees. Physiol. Plant. 12: 594-648.
Pallardy, S.G. 2008. Mineral nutrition, p. 255-285. In: S.G. Pallardy (ed.). Physiology of woody plants. 3rd ed. Elsevier, Amsterdam, The Netherlands.

Picchioni, G.A., P.H. Brown, S.A. Weinbaum, and T.T. Muraoka. 1997. Macronutrient allocation to leaves and fruit of mature, alternate-bearing pistachio trees: Magnitude and seasonal patterns at the whole-canopy level. J. Amer. Soc. Hort. Sci. 122:267-274.

Smith, M.W. 2002. Damage by an early autumn freeze varies with cultivar. HortScience 37:398-401.

Smith, M.W. and B.D. McCraw. 1998. Weed control in pecans, apples and peaches. Oklahoma Coop. Ext. Ser. Curr. Rpt. CR-6242,

Smith, M.W. and B.W. Wood. 2006. Pecan tree biomass estimates. HortScience 41:1286-1291.

Smith, M.W., B.W. Wood, and W.R. Raun. 2007. Recovery and partitioning of nitrogen from early spring and mid summer applications to pecan trees. J. Amer. Soc. Hort. Sci. 132:758-763.

Sparks, D. 1977. Effects of fruiting on scorch, premature defoliation, and nutrient status of 'Chickasaw' pecan leaves. J. Amer. Soc. Hort. Sci. 102:669-673.

Sparks, D. 1986. Pecan, p. 323-339. In: S.P. Monselise (ed.). Handbook of fruit set and development. CRC Press, Boca Raton, FL. Sparks, D. 1988. Growth and nutritional status of pecan in response to phosphorus. J. Amer. Soc. Hort. Sci. 113:850-859.

Stassen, P.J.C., H.W. Stindt, D.K. Strydon, and J.H. Terblanche. 1981. Seasonal changes in nitrogen fractions of young Kakamas peach trees. Agroplantae 13:63-72.

Taylor, B.K. 1967. Storage and mobilization of nitrogen in fruit trees: A review. J. Austral. Inst. Agr. Sci. 33:23-29.

Thor, C.J. and C.L. Smith. 1935. A physiological study of seasonal changes in the composition of the pecan during fruit development. J. Agr. Res. 50:97-121.

Titus, J.S. and S.M. Kang. 1982. Nitrogen metabolism, translocation, and recycling in apple trees. Hort. Rev (Amer. Soc. Hort. Sci.) 4:204-246.

Tromp, J. 1983. Nutrient reserves in roots of fruit trees, in particular carbohydrates and nitrogen. Plant Soil 71:401-413.

Venkatachalam, M., H.H. Kshirsagar, N.P. Seeram, D. Heber, T.T. Thompson, K.H. Roux, and S.K. Sathe. 2007. Biochemical composition and immunological comparison of select pecan [Carya illinoinensis (Wangenh. K. Koch)] cultivars. J. Agr. Food Chem. 55:9899-9907.

von Broembsen, S., P. Mulder, and B.D. McCraw. 1999. Commercial pecan insect and disease control: 2000. Oklahoma Coop. Ext. Ser. Curr. Rpt. CR-6209.

Vreugdenhil, D. 1985. Source-to-sink gradient of potassium in the phloem. Planta 163:238-240.

Weinbaum, S.A., G.A. Picchioni, T.T. Muraoka, L. Ferguson, and P.H. Brown. 1994b. Fertilizer nitrogen and boron uptake, storage, and allocation vary during the alternate bearing cycle in pistachio trees. J. Amer. Soc. Hort. Sci. 119:24-31.

Weinbaum, S.A., T.T. Muraoka, and R.E. Plant. 1994a. Intracanopy variation in nitrogen cycling through leaves is influenced by irradiance and proximity to developing fruit in mature walnut trees. Trees (Berl.) 9:6-11.

Weinbaum, S.A., F.J.A. Niederholzer, S. Ponchner, R.C. Rosecrance, R.M. Carlson, A.C. Whittlesey, and T.T. Muraoka. 1994c. Nutrient uptake by cropping and defruited field-grown 'French' prune trees. J. Amer. Soc. Hort. Sci. 119:925-930.

Wells, M.L. and B.W. Wood. 2007. Relationships between leaflet nitrogen: Potassium ratio and yield of pecan. HortTechnology 17: 473-479.

Wetzstein, H.Y. and D. Sparks. 1983. The morphology of pistillate flower differentiation in pecan. J. Amer. Soc. Hort. Sci. 108:9971003.

Wetzstein, H.Y. and D. Sparks. 1984. The morphology of staminate flower differentiation in pecan. J. Amer. Soc. Hort. Sci. 109:245-252. Worthington, J.W. and L.A. Stein. 1993. Water management, p. V-9V-20. In: G.R. McEachern and L.A. Stein (eds.). Texas pecan handbook. Texas Agr. Ext. Serv. TAEX Hort. Hndbk. 105. 